Journal of Ancient Philosophy Vol. III 2009 Issue 1

\title{
Pathos, Pleasure and the Ethical Life in Aristippus
}

Kristian Urstad

(Nicola Valley Institute \& British Columbia Institute of Technology)

For many of the ancient Greek philosophers, the ethical life was understood to be closely tied up with important notions like rational integrity, self-control, self-sufficiency, and so on. Because of this, feeling or passion (pathos), and in particular, pleasure, was viewed with suspicion. There was a general insistence on drawing up a sharp contrast between a life of virtue on the one hand and one of pleasure on the other. While virtue was regarded as rational and as integral to advancing one's well-being or happiness and safeguarding one's autonomy, pleasure was viewed as largely irrational and as something that usually undermines a life of reason, self-control and self-sufficiency. I want to try to show that the hedonist Aristippus of Cyrene, a student and contemporary of Socrates, was unique in not drawing up such a sharp contrast. Aristippus, I argue, might be seen to be challenging the conception of passion and pleasure connected to loss of self-control and hubristic behavior. Not only do I try to show that pleasure according to Aristippus is much more comprehensive or inclusive than it is usually taken to be, but that a certain kind of control and self-possession actually play an important part in his conception of pleasure and in his hedonism as a whole.

For many of the ancient Greek philosophers, the ethical life was understood to be closely tied up with notions like rational integrity, self-control, self-sufficiency, and so on. Because of this, feeling or passion (pathos), and in particular, pleasure, was viewed with suspicion. There was a general insistence on drawing up a sharp contrast between a life of virtue on the one hand and one of pleasure on the other. While virtue was regarded as rational and as integral to advancing one's well-being or happiness and safeguarding one’s autonomy, pleasure was viewed as largely irrational and as something that usually undermines a life of reason, self-control and self-sufficiency.

I want to try to show that Aristippus of Cyrene, a student and contemporary of Socrates, did not draw up such a sharp contrast. This may seem surprising since 
Journal of Ancient Philosophy Vol. III 2009 Issue 1

Aristippus is traditionally understood as a sybaritic hedonist, someone who only cares for physical pleasures at the expense of any concern for such ethical notions, like self-control and rational integrity. But this traditional interpretation, I will argue, is simply not correct. Rather, Aristippus, I claim, might be seen to be challenging the conception of passion and pleasure connected to loss of self-control and hubristic behavior. Not only do I try to show that pleasure according to Aristippus is much more comprehensive or inclusive than it is usually taken to be, but that a certain kind of control and selfpossession play an important part in his conception of pleasure and in his hedonism as a whole.

I proceed in roughly four stages. First, I argue against that aspect of traditional interpretation which has Aristippus tagged as someone upholding exclusively a sybaritic view of pleasure. I contend that a careful reading of the testimony reveals no such exclusivity on his part. Second, I take a closer look at Aristippus' intellectual context and influences with respect to the notion of pleasure. This supplies us with further reason, I argue, to suppose that Aristippus would not have construed pleasure so narrowly. Third, I attempt to uncover a more positive account of Aristippus’ notion of pleasure. And finally, I speculate on the ethical significance of pleasure according to Aristippus.

Aristippus is viewed, both by ancient and modern commentators, as holding a sybaritic view of pleasure, that is to say, one concerned exclusively with the more immediate or short-term bodily pleasures, usually associated with appetites for sex, food and drink. For instance, Cicero attributes to him, in polemical fashion, the view that pleasure is "an agreeable and delightful excitation of the sense, which is what even dumb cattle, if they could speak, would call pleasure” (De fin. II 18); and later in the same work he says that Aristippus held that we are here "like some dull, half-witted sheep, in order 
Journal of Ancient Philosophy Vol. III 2009 Issue 1

to feed and enjoy the pleasure of procreation" (II 40). ${ }^{1}$ Lucian dubs him the "sophist of pleasant sensations', and it is clear he has primarily bodily pleasure in mind since his (Aristippus') drunken condition prohibits him from actually speaking in Lucian’s sketch (Vit. auct. 12). A modern example is Guthrie, who claims that Aristippus "was a hedonist in the vulgar sense of indulging excessively in food, drink and sex...” and that his "hedonism was of the strictest sort. Pleasure was confined to bodily pleasure” (1971, 143, 174). And the list is not insubstantial that goes on in this vein. ${ }^{2}$

Let me first begin with this often made claim about sybariticism. Is there really strong evidence for this view of Aristippus? The answer here must be, not especially, or at least, not exclusively so. I start with three preliminary but important points which must be considered.

First, though one must not neglect Aristippus' more profligate tendencies, since they are indisputably there, as, among others, the reports of both Xenophon ${ }^{3}$ and Athenaeus ${ }^{4}$ clearly point out, such reports should be taken with a large grain of salt. This is because the 'voluptuous and pleasure-loving' 5 position of Aristippus no doubt inspired much contempt from contemporaries and various later thinkers (for instance, according to Diogenes Laertius, Xenophon, Theodorus and Plato are all said to have abused Aristippus because of his position on pleasure -II 65). And such contempt most likely expressed itself in exaggerated and scandalizing stories about Aristippus, where these stories were then in turn used to provide one-sided illustrations of his position on pleasure. That hedonists, even those of the most subtle and sophisticated variety, often get tarred with

\footnotetext{
${ }^{1}$ Earlier, in Book I, Cicero states clearly that it is physical enjoyment (corpore voluptatem) Aristippus is after (23).

${ }^{2}$ To mention but a few: Gosling and Taylor, 1982, 40; Rankin, 1983, 200; Kahn, 1996, 18.

${ }^{3}$ Xenophon reports that Socrates is aware that Aristippus is intemperate regarding "eating and drinking and sexual indulgence” (Mem. 2. 1. 1).

${ }^{4}$ Athenaeus claims that Aristippus “...lived amid every form of luxury and expensive indulgence in perfumes, clothes and women.” (Deip. XII 544b)

${ }^{5}$ Quoted from Aristocles, apud Eusebius, Prep. Evang. XIV. 18. 31.
} 
Journal of Ancient Philosophy Vol. III 2009 Issue 1

the brush of excess and sensualism, is, after all, not all that surprising. We need only be reminded of Epicurus who was slandered by his contemporaries (DL 10 4-8).

Second, we should see, in part, some of Aristippus' apparent levity and crudity as representing a Socratic trait, namely, his playfulness and ironical mode of presentation. Like Socrates, Aristippus, through his own brand of shock tactics and witticisms, wanted to rouse those who hear him to thought. ${ }^{6}$ Thus we ought not always take all the scandalizing and profligate things Aristippus says or does as entirely and accurately representing the underlying view or theory on his part.

But third, and perhaps most importantly, the sybaritic interpretation rides partly on a confusion wrought up over the synonymy between the two Aristippi, the former and his grandson of the same name (I return to this shortly). Moreover, many of the attributions in the sources seem to be pointing to a view of the Cyrenaics in general, failing in distinguishing between Aristippus himself and later modifications of his followers. And why is this important? Because if we look closely at the testimony we see that it is largely the Cyrenaics, and not Aristippus, who exalt bodily pleasures and who take it to occupy a central place in their ethics. ${ }^{7}$ For instance, in Diogenes' first doxographical section comprising the life of Aristippus (which he marks off from the rest of the Cyrenaics), there is no indication that bodily pleasures are viewed as paramount. To be sure, there are references to luxurious living but there are just as many, if not more, references to philosophical, intellectual, and artistic pleasures -the sorts of enjoyments hard to square with a purely sybaritic or sensationalistic conception of pleasure. This general mix of enjoyments stands in somewhat stark contrast to the following section on his successors, the Cyrenaics, where numerous explicit references are made to bodily

\footnotetext{
${ }^{6}$ See Rankin, 1983, 199.

${ }^{7}$ For example, DL II 87; Cicero, Luc. 139; Lactantius, Divin. Inst. 28. 3, 34-7.
} 
Journal of Ancient Philosophy Vol. III 2009 Issue 1

pleasure as the best kind and as occupying the final end ${ }^{8}$ with comparatively little mention (and if so, in a lower status) in the way of mental pleasures. ${ }^{9}$

That said, there is one passage in particular which is often referred to as evidence of a simple physicalist or bodily view of pleasure in Aristippus. Diogenes reports that Aristippus "defined the telos as the smooth movement (th_n lei/an ki/nhsin) that comes forth to perception" (II 85). Now we should be wary here in attributing such a claim to Aristippus. Aristocles of Messene reports that Aristippus affirmed that the essence of happiness lay in pleasures, without specification as to what sort, while his grandson, Aristippus Junior, went on to clearly define these pleasures as movements or kinetic (Eusebius, Praep. Ev. XIV. 18. 31). ${ }^{10}$ Moreover this description at II 85 seems to be best understood as one backed by a kind of radical epistemology -a view which we can almost certainly claim had not been developed by Aristippus. ${ }^{11}$ This, and the fact that there are very few non-conflated references elsewhere to kinetic pleasures in Aristippus (the elder), seems to suggest Diogenes has confused the evidence here.

In any case, setting aside likely issues of conflation between Aristippus and his grandson, the assumption here is that because Aristippus characterizes pleasure as involving some sort of physical movement that it must therefore be the bodily kind which he has primarily in mind. But strictly considered, this account, i.e. that all pleasure experiences or perceptions are influenced by underlying physical movements, need not entail such an assumption. That is, the fact that pleasure involves being affected by some kind of underlying movement in the body need not imply that the pleasure engaged in be of a direct bodily sort, like, for instance, settling into a hot bath or getting a massage. Consider, for instance, Plato's Philebus (a composition of Aristippus' time and available to him): Socrates, in giving what looks like a generic account of pleasures, speaks of

\footnotetext{
${ }^{8}$ For instance, DL II 87, 89, 90.

${ }^{9}$ Though there are perhaps a few exceptions, e.g. ibid, 89, 96.

${ }^{10}$ Notice also that Athenaeus entangles Aristippus 'and his followers' when he ascribes kinetic pleasure to them (Deip. XII, 546e).

${ }^{11}$ For more on this, see Urstad, 2008, Section I.
} 
Journal of Ancient Philosophy Vol. III 2009 Issue 1

them as affections that "penetrate through both body and soul and provoke a kind of upheaval (seismon) that is peculiar to each but also common to both of them.” (33d, italics added) Whenever he speaks of the more pure pleasures (e.g. those of expectation that the soul experiences by itself without the body, 32c; those of pure colors, sounds, shapes and smells, 51b) he never once indicates that a complexion of pleasures of this sort requires a different account from the generic one. What looks to be implied here is that a kind of common movement, both in the body and soul, is something that underlies all experiences of pleasure. ${ }^{12}$ Aristippus, if indeed we are justified in attributing this passage in Diogenes to him, need perhaps be no different in this regard.

Moreover, it is perhaps significant that Aristippus does not appear to adopt any version of the most dominant conception of pleasure in and around his time. What I am referring to here is the general restorative or replenishment view of pleasure, which seems to have its roots in Empedocles and is developed and discussed throughout many of Plato's works (and is held by pleasure-pursuers like Callicles). ${ }^{13}$ This view defines pleasure as the replenishment of a lack or the relief from distress, it is the movement that consists in the restoration of an original harmony, the so-called 'natural condition' .

Such a view does not seem to cohere with the testimony on Aristippus in the following ways. To begin with, there is no indication, as far as I am aware, of a description of pleasure in Aristippus as taking a certain direction, e.g. towards repletion. Instead, what we do find, as just mentioned, is a description of pleasure as occurring in a certain manner or as adopting a certain texture (th_n lei/an ki/nhsin, DL II 85). Withholding the strong possibility of conflation, it is far from clear what exactly is meant by this description, but, it is significant, I think, that the motion spoken of here is a kinesis and not a genesis, since it is the latter, not the former, which has more obvious

\footnotetext{
${ }^{12}$ Epicurus too appears to think that there are kinetic mental pleasures (Plut. Col. 1122e, Non Posse, 1087b).

13 See Gosling and Taylor, 1982 and Riel, 2000, for detailed examinations of this model. Gomperz, 1964, 215, too seems to suggest that Aristippus' concept of pleasure should not be seen in this light.
} 
Journal of Ancient Philosophy Vol. III 2009 Issue 1

affinities with the replenishment view. That is, pleasure as a process of coming-to-be, and therefore for the sake of something else, fits well with the view that pleasure is the process toward the natural condition, e.g. eating when hungry for sake of the restoration of the body.

Moreover, it is interesting when this sort of genesis view, attributed to certain subtle thinkers, is discussed in the Philebus (53cff). It is interesting because Socrates says that anyone holding this view will obviously mock those who claim that pleasure is the good. But while the aim of the subtlers is to show that no pleasure is the good or the goal, Aristippus is, as we have seen, clearly reported as having held that pleasure is the good or the proper final object of pursuit. Thus that Aristippus would not fit well as a candidate for a holder of the view of the subtlers perhaps gives us further reason to suppose he is not working within this replenishment model.

And finally, what is especially important to notice is that the replenishment view is mostly taken to be concerned with the more typical bodily pleasures, since it is obviously these sorts of pleasures which are best characterized as fulfillment of a lack, relief from pain, as is made clear from, among others, Plato. ${ }^{14}$ However, as we have seen, pleasures in Aristippus, though they no doubt include them, are not restricted to the bodily kind. He is, for example, said to have taken pleasure in conversation (DL II 79), fine clothes and scents (Athen. Deip. XII 544b). I mention the pleasures of conversing or learning since they seem quite disparate from some of the more restrictedly sybaritic ones like satisfying a desire for sex; however, as Plato argues for in the Republic (585bff), such pleasures can nevertheless be conceived of as pleasures of filling or replenishment. On the other hand, the latter example regarding the enjoyment of certain scents or perfumes is somewhat more intriguing. Both in the Republic (584b-c) and Philebus (51b) Plato looks to reserve a special place, seemingly somewhere outside of his usual replenishment analysis, for such partially aesthetic pleasures (along with those of hearing

\footnotetext{
${ }^{14}$ For example, "However, most of the so-called pleasures which reach the soul through the body, as well as the most intense ones are of this form -they are some kind of relief from pain." (Rep. 584c)
} 
Journal of Ancient Philosophy Vol. III 2009 Issue 1

and sight). That is, he certainly does say that such pleasures are not preceded by any sort of distress, and even though there is some controversy among scholars here ${ }^{15}$, it is, at least prima facie, difficult to see them as belonging to the view that pleasure is the correcting of an imbalance or replenishment of a natural lack. This might be taken as further suggestive of the view that it is not the restorative model of pleasure Aristippus is promoting.

Adherents of the view that Aristippus adopts something like a bodily view of pleasure might appeal to Plato's Protagoras. They might appeal to the Protagoras because the standard interpretation there seems to be that in that particular bit of the dialogue where pleasure is discussed Socrates has in mind something like a coarse empiricist view of pleasure, pleasure as a uniform sensation ${ }^{16}$; not only is phenomenological uniformity often seen in conjunction with bodily pleasure, but Socrates often mentions examples of physical pleasures there. Thus since Aristippus was almost certainly well acquainted with and influenced by this work $^{17}$, it is also possible that he had picked up, or found corroboration in, the notion of pleasure there standardly taken to be expressed by Socrates.

A major difficulty with such an appeal would be that it is not at all clear that Socrates in the Protagoras actually adopts the view that is standardly attributed to him. Actually, it is in itself significant that Socrates, in this work, does not really say that

\footnotetext{
${ }^{15}$ See, e.g., Gosling and Taylor, 1982, Chap. 6-8.

${ }^{16}$ For example, see Irwin, 1977, 111; Gosling and Taylor, 1982, 177, think it tempting to treat pleasure in the Protagoras 'as a sensation like warmth'. This empiricist conception is commonly assumed because in the Protagoras it appears (to these interpreters) that the only differentiation made between kinds of pleasures is quantitative, the amount of pleasure achieved (356b), a criterion friendly to a conception of pleasure as a distinct and commensurable sensation state (see also Irwin, 1995, 90).

${ }^{17}$ For more on the relationship between Aristippus and the Protagoras, see Urstad, 2008, Section II.
} 
Journal of Ancient Philosophy Vol. III 2009 Issue 1

much about what he supposes pleasure to be. ${ }^{18}$ It is true that he gives examples of pleasant things like food, drink and sex (353c) -examples which appear to conform to the standard view, but we ought to observe that he does so only within the context of his description of the akratic individual on behalf of the many. The labelling and employment of such pleasures here of course makes good protreptic sense, but it says little about Socrates' conception of pleasure in that dialogue as a whole.

There are however several clues throughout the dialogue which do fill out this conception somewhat. For instance, prior to that segment of the discussion concerning pleasure and the pleasant life (351b), Prodicus is made to distinguish between 'to be pleased' and 'to be cheered', and to associate bodily pleasures with the former and mental pleasures with the latter. Plato's point here is not just to communicate mere pedantry on the part of Prodicus. What Plato is also doing, it might be suggested, is signalling to us that the ensuing discussion of pleasure is to be understood in its widest or most comprehensive sense.

Moreover, later, at the near closing of the case for the denial of akrasia, Socrates says some things which ought to strike those who adhere to the standard view as peculiar. First, at 357b, Socrates says "what exactly this art, this knowledge is (of pleasures and pains) we can inquire into later”. We might wonder why, if pleasure was some simple uniform sensation, Socrates would think he has not yet exhausted just what this art of measurement is or consists in. That Socrates would withhold certainty with respect to this suggests he has a somewhat more open-ended conception of pleasure (and pain) than the standard interpretation calls for.

And indeed, something like this seems to be given further validation when Socrates goes on to say to Prodicus "I beg indulgence of Prodicus who distinguishes among words; for whether you call it (the pleasant) 'pleasant' or 'delightful' or ‘enjoyable', whatever manner you please to name this sort of thing...” (358a-b, italics

\footnotetext{
${ }^{18}$ On recognition of the fact that Socrates there makes little attempt to define pleasure at all, that he never delves into its nature, see Riel, 2000, 9 and D. Frede, 1999, 349.
} 
Journal of Ancient Philosophy Vol. III 2009 Issue 1

added). It is hard not to see such terms as connoting a very wide variety of positive psychological states. This surely indicates Socrates' refusal to allow any narrowing of that wide range of meaning which the words accept. So that Socrates so readily exploits their conflation or synonymy again suggests that when he uses the word 'pleasure' or 'pleasant' he has something broader in mind than the standard uniform sensation view (in fact, we ought to notice that Socrates has already used 'enjoy' as a synonym at 354c-d).

We should also notice that the term hedone itself is used in many places in the Protagoras, and in a way both Socrates and the everyday person would use it, and in these cases the referent has nothing to do with physical or bodily pleasures. For instance, When Socrates and young Hippocrates arrive at the house of Callias, Socrates says of the pupils of Protagoras, that their “...dance simply delighted me (h(/sqhn i)dw/n) when I saw how beautifully they took care never to get in Protagoras' way.” (315b); at 347b Socrates states: "I leave it up to Protagoras, but if it’s all right with him (h(/dion)...”; and following this he says to him: "I would be glad to settle (h(de/wj a)n e)pi te/loj e)/lqiomi) in a joint investigation with you.” (347c) All this is ordinary, everyday Greek usage of the term, and it clearly betrays a broad application.

Thus there are two important distinctions to be made here, both implying openendedness. In the first case, Socrates is saying (to Prodicus) that terms like 'enjoyment', 'delight', etc, words which connote a wide range of positive psychological states, can mean the same as, or be used interchangeably with, or subsumed under, the term hedone. In the second case, variations of hedone itself can be seen to be used in a variety of contexts where different sorts of pleasures are being implied.

Furthermore, it may be significant that Socrates includes the 'defence of one's city' as one of the compensating pleasures (for the prior undergoing of such painful things as military training and starvation diets) mentioned at 354b. The pleasure here seems to amount to something like the satisfaction of knowing that one's efforts and deprivations have contributed to the city's safety. Again, whatever sort of pleasure this is exactly, it is not done full justice by the standard view. Thus it seems most reasonable to understand the notion of pleasure in the Protagoras as a largely inclusive and 
heterogeneous one, compatible with a wide field of experiences or psychological states, like positive sensations, attitudes, perceptions, or feelings.

Finally, one might comment on Socrates' opening question to Protagoras at the start of their discussion on pleasure: "Now, if he (the everyday man) completed his life, having lived pleasantly, does he not seem to you to have lived well?” (351b) On its own, the expression 'the pleasant life' is undeniably vague, and it seems this is precisely why Socrates employs it. This is corroborated by the expression he takes it to be synonymous with, 'to live well'. No doubt in normal Greek parlance 'to live well' involves saying that one is leading a comfortable life, having one's bodily needs met, in a word, that one is getting one's basic bodily pleasures ${ }^{19}$; but it also standardly connotes the idea of a life of various sorts of satisfactions and enjoyments, moral ones, aesthetic ones, etc.

In sum then, if Aristippus was exposed to, or influenced by, the Protagoras, it need not be an indication that he turned to, or found corroboration in, a bodily view of pleasure. In fact, given what has just been said, it is probably more likely that what would have resonated in him is a much more inclusive sense of the notion of pleasure.

Another important piece of work during this time to take into consideration with respect to Aristippus and pleasure is Plato's Philebus. In fact, for various reasons, many scholars have seen this dialogue in close connection with Aristippus. ${ }^{20}$ Part of what Socrates does there is that he illuminates and enlarges the coarse and vague application of the term 'pleasure' as it is used by the younger interlocutors in the early stages of the discussion. At the outset, Protarchus denies that good and bad pleasures are unlike each other in so far as they are pleasures or qua pleasures (13c5). He rejects Socrates' view that the temperate and intemperate person are undergoing different pleasures (12c8-d4). According to Protarchus, pleasure is the same thing regardless of what occasions it or of what it points to, so that the temperate and intemperate are simply getting the same thing from different sources. This suggests he understands pleasure simply as some kind of

${ }^{19}$ On the closeness between 'living well' (and such similar expressions) and pleasure in Greek thought, see Stokes, 1986, 366.

${ }^{20}$ For instance, Merlan, 1960, 33-5; Zeller, 1963, 112; Irwin, 1995, 16. 
sensation or feeling which is entirely distinct from the activity associated with it, a “kick...a mere aftereffect or epiphenomenon” as D. Frede (1993, xviii) has put it.

Socrates' disagreement with Protarchus is made clear right from the very beginning of their dialogue when he makes the preliminary claim that an examination of the nature (phusis) of pleasure reveals that it is a 'complex' thing and that 'in fact it comes in many forms' (12c). The gist of Socrates' ensuing argument might be put as follows. He argues that 'pleasure' is not a name for a single intuited quality of feeling or unitary phenomenon at all, anymore than there is one concretely intuited quality of experience called 'color'. Both are something like abstract class concepts. One does not directly experience pure pleasure as such (just as one does not experience pure color as such), rather, what one does experience are particular instances or species of pleasure (or instances of color -say, blue or green). The way particular instances of pleasure are to be identified and distinguished from one another is presumably by mentioning something about the causes, activities or qualities of experience with which they are associated.

Whatever precisely Socrates may have in mind here, the general point seems obvious enough. Instances of pleasure are not to be identified purely by some feelingelement over and above the pursuits enjoyed, something usually characteristic of bodily sensations, but rather, by certain non-affective properties such as perhaps their causes, intentional objects (35b), etc. Socrates is thus rejecting the possibility of completely separating pleasure from the activities or pursuits in the way that his interlocutor Protarchus seems to be doing (and which, it might be added, is more typical of modern hedonists like Bentham and Mill).

Now, I am not proposing that Aristippus has in mind an account of pleasure like Socrates does in the Philebus. ${ }^{21}$ All I am suggesting is that the availability of this dialogue and Aristippus' likely familiarity with it and other works like the Protagoras, ${ }^{22}$

\footnotetext{
${ }^{21}$ Of course Socrates in the Philebus is not extolling hedonism. Pleasure turns out to receive fifth position on the candidate list for the highest good (67a).

${ }^{22}$ We should notice that Plato, throughout his works, uses a variety of suggestive idioms in describing pleasure. For instance, at Gorgias 496e drinking is said to be a filling of a deficiency
} 
Journal of Ancient Philosophy Vol. III 2009 Issue 1

at least makes it plausible to think that Aristippus was indeed aware of, and receptive to, the plasticity of the concept of pleasure, its multifarious nature-circumstances which we might reasonably suppose would not speak much in favor of the adoption of a narrow bodily view on his part.

There is not a whole lot in the historically proximate testimony which gives us much indication of how it is Aristippus conceived of the nature of pleasure. It is true that in the Memorabilia Socrates mainly attributes certain kinds of crude bodily pleasures to Aristippus (esp. 2. 1. 1); as Gosling and Taylor point out, Xenophon, in that dialogue, seems to make him "the champion of the sybaritic life" (1982, 40).

However, we should keep two important points in mind. One, as Diogenes reports, Xenophon was no friend of Aristippus (II 65), ${ }^{23}$ providing us with some reason to think he makes Socrates parody or exaggerate Aristippus' outlook somewhat. And two, we should notice that it is Socrates who attributes certain kinds of pleasures to Aristippus while Aristippus himself never actually says anything about the sorts of pleasures which concern him. The only pertinent thing he says in this regard is that he wishes for a life of the greatest pleasure (2. 1. 9). There is admittedly little information in this, but we should keep in mind that he does use hedone here, and he does so without pointing to any pleasure-sources. And as we have seen, this term can encompass a wide variety of psychological experiences or states. Such inclusiveness is also hinted at in the fuller expression "a life of the greatest pleasure", which, it might be noticed, nearly mirrors the

and thereby a pleasure, and at 499e we are told we must perform good pleasures. Again, this seems to betray the largely open-ended understanding of pleasure at the time.

${ }^{23}$ Grote, 1865, III, 538: "Xenophon was a man of action, resolute in mind and vigorous in body, performing with credit the duties of the general as well as of the soldier. His heroes were men like Cyrus, Agesilaus, Ischomachus -warriors, horsemen, hunters, always engaged in active competition for power, glory or profit, and never shrinking from danger, fatigue, or privation. For a life of easy and unambitious indulgence... he had no respect. It was on this side that the character of Aristippus certainly seemed to be...the most defective.” 
Journal of Ancient Philosophy Vol. III 2009 Issue 1

somewhat innocuous Protagoras passage discussed earlier (351b). Thus it is largely left open what exactly Aristippus has in mind here.

There is however one peculiar term indirectly attributed to Aristippus in the Memorabilia perhaps worth mentioning. In Prodicus’ fable, Vice's speech, whose words are meant to represent the views of Aristippus, contains the use of euphrainesthai of sexual love (2. 1. 24). The use of this term in conjunction with this particular object is somewhat unconventional; ${ }^{24}$ in this context we would have expected hedesthai, which, though it, as we have seen, carries a wide range of enjoyments, is more often paired with coarse physical pleasures. Euphrainesthai has some etymological connection with mind or intelligence, phronesis. Indeed, as previously noted, the same author (Prodicus) is made by Plato in the Protagoras to make explicit this very distinction. At 337c, Prodicus takes euphrainesthai and hedesthai to mark a dividing line between the enjoyment of mental activities and physical or bodily activities respectively (and Socrates tells us that many of those present agreed with this). Thus if we view Vice's use of term in connection with what Prodicus is made to say at Prot. 337c, we may have reason to suspect that for Aristippus the enjoyment of a physical pleasure like sex is in part a mental one. This is speculation which outruns the Memorabilia text however, thus I leave it as it is.

Outside of the historically proximate testimony, there are, I believe, three illuminative characterizations of pleasure attributed to Aristippus. The first two are to be found in the roman author Aelian and the Christian humanist Erasmus, and the other, in the physician and philosopher Galen. Aelian reports that “Aristippus seemed to speak with particular conviction when encouraging people neither to bother themselves in retrospect over that which has passed, nor to toil in prospect of things to come. For this kind of behavior is the mark of happiness and proof of a gracious frame of mind (eu)qumi/a).” (Var. Hist. 14. 6; 208 in Mannebach) ${ }^{25}$ Erasmus praises Aristippus with

\footnotetext{
${ }^{24}$ See Taylor, 1991, 138.

${ }^{25}$ Some commentators take this fragment to be beyond doubt preserving Aristippus' own words (see Guthrie, 1975, 494).
} 
possessing a kind of "joyful freedom”. ${ }^{26}$ And Galen attributes to Aristippus a conception of pleasure which he refers to as a kind of disposition of mind whereby one becomes indifferent to pain and hard to be enticed or beguiled (a)na/lghtoj kail dusgoh/teutoj). ${ }^{27}$

The principal observation that springs to mind is the fact that all of these descriptions connote certain broad states of mind which are not restricted to bodily pleasures (though this is not to suggest that such pleasures or sensations are excluded or cannot be incorporated by such descriptions). Euthumia is perhaps akin to 'gladness' or 'joy' and just translates as having one's appetitive self (thumos) in a good state. This clearly captures something closer to a kind of general frame or disposition of mind than it does a particular pleasant episode or bodily sensation. Indeed, Democritus (who was apparently the first to employ this term in connection with one's telos) is reported to have claimed that euthumia is not the same as hedone (DL 9. 45). Whatever we are to make of this, clearly there is some sort of distinction that is understood or permitted by these terms.

Moreover, the fact that euthumia is paired in the Aelian passage with happiness is perhaps also suggestive. Eudaimonia has overtones of prosperity and external well-being while euthumia seems to imply more of an internal state and one which is not so dependent on external factors. But bodily pleasures, it might be thought, are usually tied more to external circumstances and contingencies than are states of gladness, joy or certain positive frames or dispositions of mind. Thus that Aristippus allegedly speaks of both eudaimonia and euthumia perhaps indicates that he is making room in his account not only for sensual or bodily pleasures but for mental, attitudinal, dispositional, etc, ones as well. Such inclusion seems to be further suggested by Erasmus' 'joyful freedom' and by the controlled or self-possessed disposition mentioned by Galen -they each appear to

\footnotetext{
26 "It does not seem to me misplaced, following the playful sanctity of Socrates and the joyful freedom of Aristippus, to move on to Diogenes of Sinope, who far surpasses all others with the inexhaustible charm of his words. In the end, though, with all their differing qualities, I have put these three on a par." (Apophthegmata, in Opera Omnia, ed. J. Leclerc; see also Erasmus, Apophthegmes, 1969, 68. 62.)

${ }^{27}$ In Opera Omnia, ed. Kühn, Vol. 19, 230; see also Grote, 1865, 551, n. a.
} 
Journal of Ancient Philosophy Vol. III 2009 Issue 1

express, and to allow for, states of mind broader in scope than particular episodes of pleasures or sensations. $^{28}$

Finally, there is one curious bit of repartee which perhaps deserves some discussion. Diogenes reports the following about Aristippus.

Being asked how Socrates died, he answered, "As I would wish to die myself.” (II 76)

If Aristippus has in mind something like Socrates' manner of death as it is depicted in Plato's Phaedo, this is a striking claim for a sybaritic hedonist to make. For surely it is difficult to make much sense of this under a bodily sensation view of hedonism. Forget talk of pleasurable sensations, to linger for weeks in a bare prison cell, ${ }^{29}$ with legs bonded to fetters, only to finally die of hemlock poisoning ${ }^{30}$ seems to be a case of nothing else but painful sensory experiences. What then might Aristippus mean $?^{31}$

A look at Socrates' portrayal on that last day might provide us with a clue. Of utmost significance is just how joyful Socrates appears to be throughout (e.g. 58e) and the good cheer or contentment he shows in the face of his death (e.g. 117c4). It is clear that this joy has little to do with bodily pleasures; not only do the physical circumstances speak against it, as mentioned, but Socrates himself in his so-called 'defense speech' of the philosopher explicitly repudiates most physical pleasures (e.g. 64d2-7). Socrates’ joy, it might be suggested, seems to be connected to the strength with which he faces what

\footnotetext{
${ }^{28}$ Indeed, Grote, 1865, 551, is absolute in taking the account of pleasure attributed to Aristippus by Galen to be 'a very different doctrine' from the sensation model held by the younger Aristippus.

${ }^{29}$ A month, according to Xenophon (Mem. 4. 8. 2).

${ }^{30}$ Despite how Plato depicts Socrates' final moments, the effects of ingesting hemlock must have been dreadful (see Gill, 1973).

${ }^{31}$ Perhaps one way to make sense of this is to see Aristippus as a hedonist who believes in an afterlife and in its posthumous rewards and punishments. He might thus justify suffering the pains and cutting his life short because of the greater sensory pleasures promised for him in the afterlife. This is a possibility but I see no suggestion of it in the testimony.
} 
cannot be changed, it seems to be born of someone who realizes that his state of mind is entirely within his own power and is the sort of thing that no one can take away from him, whatever else they may take away. ${ }^{32}$ People can impose physical pain on Socrates, or deprive him of pleasurable sensations, but they cannot prevent him from adopting a certain pro-attitude to things or approaching things in a certain joyful way. If something like this is on the right track, greater sense might be made out of Aristippus' alleged admiration and approbation of Socrates' death. And if this is the case, it would seem to provide further indication that Aristippus adheres to a quite open and flexible account of pleasure.

Thus we may, I believe, safely conclude something like the following. Sensations and bodily pleasures are surely accommodated by, or make up a part of, Aristippus' conception of pleasure, but there is little reason to believe it is exhausted by them. It is best to see it as one involving a significantly wide field of positive psychological states.

Much of the testimony on Aristippus points very distinctly to a concern for a kind of inner emancipation or independence of mind in the handling of pleasures. What we get, in effect, is a picture of someone who seems to break with the particular tradition mentioned at the outset - where pleasure was viewed as largely irrational and as something that usually undermines a life of reason, self-control and self-sufficiency - by emphasizing a kind of focus on the internal employment or management of pleasures, whatever kind they may be. Consider simply a few examples:

"The one to master pleasure is not he who abstains but he who employs it without being carried away by it -just as being a master of a ship or of a horse is not abstaining from using them, but directing them where one wishes" (Stob. Ecl. 3.

\footnotetext{
${ }^{32}$ See Seneca, Letters 23. 4-5 for a description of 'joy' which might be seen in part to bear
} witness to Socrates' frame of mind near his death. 
Journal of Ancient Philosophy Vol. III 2009 Issue 1

17. 17, italics added; see also DL II 75).

"Aristippus, while clothed in purple and anointed with perfumes, was not less temperate than Diogene; for just as if somebody had equipped his body with the ability to be untouched by fire, he would be of good cheer even if he entrusted his person to Etna, so too anybody who has equipped himself well for pleasure will neither, when engulfed in it, get hot nor burn nor melt.” (Maxim. Tyr. 1. 9, italics added $)^{33}$

By paralleling the effects of pleasure with the effects of something as powerful and destructive as fire, the latter quote attests to the strongly cautionary and admonitory perception of pleasure at the time. We might see this as further serving to accentuate Aristippus' tremendous quality of self-mastery; like someone walking straight into a burning fire and not suffering from the flames and heat, Aristippus appears to indulge in pleasures without being subjugated or harmed in any way by their effects.

Aristippus' suggestion seems to be that it is some sort of precondition for feeling pleasure in the more enriched sense that one is not 'swept away' by it. It is not the abolishment of control or self-possession, but rather, the accompaniment and exercise of it which makes for the experience of pleasure to be a wholehearted one. Indeed, one might make a case, perhaps a somewhat conjectural one, that Aristippus actually takes some sort of control or self-possession to constitute a very part of the experience of pleasure. In support of this, I primarily have in mind the descriptions of pleasure attributed to Aristippus by Aelian and Galen. Aelian, it will be recalled, imputes to Aristippus the term eu)qumi/a and Galen a conception of pleasure whereby one becomes indifferent to pain and hard to be enticed or beguiled (a)na/lghtoj kai \dusgoh/teutoj). Euthumia, as mentioned, carries the basic sense of having one's emotional and appetitive

\footnotetext{
${ }^{33}$ This claim of maximal flexibility and autonomy, moreover, looks to be extended to almost all situations: "He was capable of adapting himself to place, time and person, and of playing his part appropriately under whatever circumstances.” (DL II 66)
} 
Journal of Ancient Philosophy Vol. III 2009 Issue 1

self in a good state. ${ }^{34}$ Democritus' understanding of the term is that it is "that in accordance with which the soul goes along calmly and with good balance...” (DL 9. 45). Democritus' adverbial description might be taken to suggest that pleasure is not separated from the way it is approached, engaged in or attended to. If Aristippus has something like this in mind it might signal that he takes a calm and controlled approach or engagement to constitute a very part of the experienced pleasure.

Galen's choice of terminology is also interesting, especially dusgoh/teutoj, which means something like 'hard to seduce by enchantments' (o( go/hj is a sorcerer or an enchanter). A look at Plato's use of gohteu/w in the Phaedo is perhaps illustrative because it comes in a context of expressing a view about certain pleasures on the condition of the subject. The soul cannot attain to the pure realm of the intellect if it lives a life of bondage to the body "bewitched (gegohteume/nh) by physical desires and pleasures to the point at which nothing seems to exist for it but the physical...” (81b) The general idea here is that certain pleasures put a spell on the subject, or deceive or manipulate him. In contrast, Aristippus is said by Galen to be upholding a conception of pleasure which includes immunity from such effects. Again, the suggestion here might be that a sort of unbeguiledness, this frame of mind which renders the person who has it free from certain enslaving influences, turns out to play a constitutive part of the total pleasure-experience. The enjoyment of say certain bodily pleasures will be somewhat incomplete or impoverished without the element of a kind of internal control or selfpossession, an element which Aristippus might be taking as part and parcel of the overall appropriate enjoyment.

If this overall reading of Aristippus is on the right track, it should be viewed as fairly ethically significant. According to Aristotle, well-being or happiness (eudaimonia) is complete in so far as it achieves everything we want and it is self-sufficient if it lacks nothing that we need to achieve all our desires (EN 1097b20-21). It is this concern for self-sufficiency that appears to be given particular emphasis here by Aristippus. Since

\footnotetext{
${ }^{34}$ See Gosling and Taylor, 1982, 30.
} 
control and self-possession are in some way intimately connected to pleasure and its pursuit, it becomes more unlikely that Aristippus will have his desires thwarted, and so experience frustration because of it. It is this sort of autonomy which might give him good reason to think his happiness to be invulnerable -a crucial aim for all Greek ethicists.

One final point. It is interesting that, apart from a few contentious anecdotes, nowhere do we meet with much hint of a breach with social morality on Aristippus' part. Perhaps there is some sort of connection here with Aristippus' appeal to self-control and self-sufficiency. After all, it is often those who lose control of themselves, in the sense of being unable to gain mastery over their own desires, who become susceptible to hubristic behavior. Indeed, Socrates (who, we remember, was closely associated with Aristippus) in Xenophon suggests something remarkably similar. What Xenophon continually stresses is Socrates' mastery over the appetites that trouble ordinary people, and which typically motivate unethical conduct. In Xenophon, self-control (enkrateia) forms the basis or core of Socratic ethics; in the Memorabilia, Socrates says that enkrateia is the foundation of all virtue (1. 5. 4). Since our focus here is on the moral virtues, let us see how enkrateia, according to Socrates, connects up with justice and friendship. In Xenophon's Apology, he says,

"Who is there in your knowledge that is less a slave to his bodily appetites than I am? Who in the world more free, for I accept neither gifts nor pay from any one? Whom would you with reason regard as more just than the one so reconciled to his present possessions as to want nothing beside that belongs to another?” (16, italics added)

According to Socrates, injustice seems to come about in the following sort of way. The individual who lacks enkrateia is constantly in need of money, because he is always looking for the means to satisfy his desires. The danger of injustice here is that he will seize and appropriate the goods of others to satisfy his avariciousness. On the other hand, the individual who practices enkrateia, he who has perfect control over his desires, 
Journal of Ancient Philosophy Vol. III 2009 Issue 1

will have no need for money, and so no need to help himself to the goods of others. In a word, he who needs little and controls his appetites will not be prompted to commit unjust actions towards others, the enkratic individual will end up being "fair in his dealings” with others (Mem. 2. 6. 5). Now, certainly, there is no developed theory like this in Aristippus with respect to social morality or a concern for others. Nor, correspondingly, is there any indication in the above reading of Aristippus that he will never wind up in breach of the boundaries of morally expected behavior. However, if I am right about Aristippus, whatever the exact details, this is certainly a comprehensive and regulated approach to pleasure and to hedonism, one that does not, on the whole, run foul of many of the ordinary Greek ethical commitments or concerns.

\section{Bibliography}

Frede, D. 1993. Plato: Philebus. Indiana. Hackett Publishing Company.

— 1999. "Rumplestiltskin's Pleasures: True and False Pleasures in Plato’s Philebus”.

In Plato 2, edited by Gail Fine. Series: Oxford Readings in Philosophy.

Gill, C. 1973. “The Death of Socrates” The Classical Quarterly. Vol. 23 No. 1. 25-28.

Gomperz, T. 1964. Greek Thinkers. Vol. II. Great Britain: William Clowes and Sons Limited.

Gosling and Taylor. 1982. The Greeks on Pleasure. New York: Oxford University Press. Grote, G. 1865. Plato and the Other Companions of Socrates. Vol. III. London: W. Clowes and Sons.

Guthrie, W. K. C. 1971. Socrates. Cambridge: Cambridge University Press.

— 1975. A History of Greek Philosophy. Vol. III. Cambridge: Cambridge University Press.

Irwin, T. 1977. Plato’s Moral Theory. New York: Oxford University Press.

— 1995. Plato's Ethics. New York: Oxford University Press.

Kahn, C. 1996. Plato and the Socratic Dialogue. Cambridge: Cambridge University Press.

Merlan, P. 1960. Studies in Epicurus and Aristotle. Wiesbaden. 
Journal of Ancient Philosophy Vol. III 2009 Issue 1

Rankin, H.D. 1983. Sophists, Socratics and Cynics. New Jersey: Barnes \& Noble. Riel, G. 2000. Pleasure and the Good Life: Plato, Aristotle and the Neoplatonists. Leiden: Brill.

Stokes, M. C. 1986. Plato's Socratic Conversations. London: The Athlone Press. Taylor, C. 1991. The Protagoras. Clarendon Series. Oxford: Clarendon Press. Urstad, K., 2008, "Prudence, Rationality and Happiness in Aristippus”, Gnosis, Volume IX, No 2.

Zeller, E. 1963.Outlines of the History of Greek Philosophy. London: Routledge \& Kegan Paul LTD. 